\title{
The Effect of Entrepreneurship Education on Entrepreneurial Intention: An Experimental Study on Undergraduate Business Students
}

\author{
Selma Kalyoncuoğlu ${ }^{1}$ (Corresponding author) \\ Faculty of Economics and Administrative Sciences, Gazi University \\ Muammer Bostanci Cad., No: 4, 06500, Besevler/ANKARA/TURKEY \\ Tel: $903122161253 \quad$ E-mail: selmakalyoncu@gazi.edu.tr
}

\begin{abstract}
Belgin Aydintan ${ }^{2}$
Faculty of Economics and Administrative Sciences, Gazi University

Muammer Bostanci Cad., No: 4, 06500, Besevler/ANKARA/TURKEY

Tel: 903122161206 E-mail: abelgin@gazi.edu.tr
\end{abstract}

Aykut Göksel ${ }^{3}$

Faculty of Economics and Administrative Sciences, Gazi University

Muammer Bostanci Cad., No: 4, 06500, Besevler/ANKARA/TURKEY

Tel: 903122161234 E-mail: agoksel@gazi.edu.tr

Received: May 6, 2017 Accepted: July 10, $2017 \quad$ Published: July 10, 2017

doi:10.5296/jmr.v9i3.11282 URL: https://doi.org/10.5296/jmr.v9i3.11282

\begin{abstract}
Assistant Professor of Marketing, Department of Business Administration

2 Associate Professor of Management, Department of Business Administration

3 Associate Professor of Management, Department of Business Administration
\end{abstract}

The main aim of this study is to reveal the effect of entrepreneurship education on entrepreneurial intentions of students. Participants of this study in which field experiment was carried out consisted of experimental group involving 207 participants who were exposed to experimental stimulus (entrepreneurship education) and control group involving 


\section{Macrothink}

131 participants who had characteristics similar to experimental group but who were not exposed to experimental stimulus. Within this scope, this study was carried out by applying pre-test and post-test at the beginning and in the end of the term to measure entrepreneurial intentions of undergraduate students at the Department of Business, Faculty of Economics and Administrative Sciences, Gazi University who enrolled in the university the same year, and who were divided into two groups as experimental (received entrepreneurship education within 15-week syllabus) and control (did not receive entrepreneurship education). Findings of the study show that there was a statistically significant difference between the entrepreneurial intentions of students before (beginning of term) and after (end of term) receiving entrepreneurship education. While no significant difference was found in two dimensions of entrepreneurial intention namely "innovation and action" and "family support", there were significant differences in the dimensions of "determination and perseverance", challenges of starting business" and "negative thoughts on running one's own business". Furthermore, it was found that scores of experimental group in these three dimensions after receiving entrepreneurship education were higher than their scores before the education. On the other hand, compared to experimental group, control group did not show any significant difference both in their general entrepreneurial intentions and in each dimension of entrepreneurial intention.

Keywords: Entrepreneurship, Entrepreneurial Intention, Entrepreneurship Education, Experimental Study, Undergraduate Business Students. 


\section{Introduction}

The concept of entrepreneurship has become a widely-studied topic to which a great deal of importance is attached day by day as both individuals and countries need it to move forward. It is obvious that entrepreneurs who introduce creative and innovative business ideas in economic development and who start businesses which constitute the cells of economy are extremely valuable for countries in terms of their technology and innovation policies and these entrepreneurs are essential building blocks of countries' economies. It is of significant importance that universities provide entrepreneurship education for prospective entrepreneurs so that they can improve their innovative and creative thinking skills effectively since they are driving force of economic development in a way that future businesses can be run via scientific management principles. Within this regard, the fact that entrepreneurship education has been included in national policies in creating and increasing entrepreneurial intention which is an indicator of planned entrepreneurial behaviour makes the topic of the study highly essential and imperative. The main question posed in the study is "whether entrepreneurship education given to undergraduate business students will increase their entrepreneurial intentions in a motivating manner." As distinct from other studies in the literature, the present study measures and compares both experimental group (received entrepreneurship education as experimental stimulus) and control group (did not receive entrepreneurship education) in the beginning and at the end of the term in order to investigate the possible effects of entrepreneurship education. In this way it aims to find whether entrepreneurship education has motivating effect on students' entrepreneurial intentions. Before moving on to the details of the study, it would be useful to give explanations of some concepts for better understanding.

Entrepreneurship is defined in two ways by Tang and Koveos (2004). The first definition is termed as "venture entrepreneurship" which means "Any attempt at new business or new venture creation such as self-employment, a new business organization, or the expansion of an existing business by an individual, team of individuals, or established businesses". The second definition termed as "innovation entrepreneurship" emphasizes invention and technological advancement in the economic unit (Tang \& Koveos, 2004, p. 162). Those two different definitions may be consolidated as follows: Entrepreneurship is the process hereby an individual or group of individuals use organized efforts to pursue opportunities (Shane \& Venkataraman, 2000, p. 220) to create value and growth by fulfilling wants and needs through innovation and uniqueness, no matter what kind of resources the entrepreneur currently has. Throughout the world, entrepreneurs are found in all professions; ranging from education, medicine, research, law, architecture, engineering to social work, distribution and the government, and they come in every shape, size, and colour and from all backgrounds (Hisrich, Peters \& Shepherd, 2005, p. 8; Baron, 1998, p. 277). There are some common themes in the entrepreneurship concept (Coulter, 2003, p. 4-6; Hisrich et al., 2005, p. 8) such as entrepreneur (as a decision maker) (Olson, 1986, p. 35), innovation, organization creation (Bygrave \& Hofer, 1991, p. 14), creating value, taking place in both profit and non-profit environments, growth, uniqueness, process, devotion of the necessary time and effort. As can be seen from these common features, entrepreneurs seek out opportunities for personal gain 
and ensure that resources are constantly being reallocated in a manner that improves efficiency. In the absence of entrepreneurs, resources continue to be devoted to functions where returns are low, leading to an ossified economy in which resources are under used (Acs \& Storey, 2004, p. 873).

Entrepreneurship education and teaching programs are influencing students' entrepreneurial intentions and behaviours (Fayolle \& Gailly, 2004). It is expected that by undergoing formal entrepreneurial education training, individuals will acquire knowledge and skills necessary to take on the challenges of setting up one's own business (Roxas, Cayoca-Panizales \& Jesus, 2008; Clercq \& Arenius, 2006).

Some previous studies in the literature indicated that entrepreneurship education has negative and positives effects on entrepreneurial intention. Oosterbeek, Praag, and Ijsselstein (2010) claimed that graduate students who took entrepreneurship education in their universities had low level entrepreneurial intention furthermore entrepreneurship education affected their entrepreneurial intentions negatively. Similarly, McLarty (2005) found in his study in the UK that 39 students who took entrepreneurship education did not feel ready for setting up their own entities and the education programme was not sufficient to create a new entity. On the other hand, Kourilsky and Esfandiari (1997), Charney and Libecap (2000), Galloway and Brown (2002), Balaban and Ozdemir (2008), Tagraf and Halis (2008), Izedonmi and Okafor (2010), Huber, Sloof, and Praag (2012), Karlsson and Moberg (2013), Ulukoy, Demireli and Kahya (2013), Donnellon, Ollila, and Middleton (2014), Elert, Andersson, and Wennberg (2015) showed in their studies that entrepreneurship education had positive contributions to taking risks, developing entrepreneurial skills, and setting up new ventures. Moreover, Bozkurt, Aslan, and Goral (2011) reached similar results and found that students who took entrepreneurship education had more entrepreneurial intentions than those who did not take.

\section{Literature Review}

Entrepreneurship can be considered as a process in which organized efforts are utilized to make best use of opportunities to create value, in this way wants and needs are obtained thanks to innovation and uniqueness, no matter what resources are available for entrepreneurs (Coulter, 2003, p. 4-6; Hisrich et al., 2005, p. 8). A number of authors (Bird, 1988; Katz \& Gartner, 1988; Krueger \& Brazeal, 1994) argue that such entrepreneurial process is a planned and purposive act and individuals are active agents in the process which means that they engage in entrepreneurship intentionally not by accident, and it is a result of their choice (Obschonka, Silbereisen \& Schmitt-Rodermund, 2010).

Entrepreneurship has become an important issue for not only individuals but also companies in emerging countries in recent years. As a part of entrepreneurship process, entrepreneurial intentions which are owned by individuals is highly effective in their entrepreneurial efforts and success. Entrepreneurial intention can be defined as "the search for information that can be used to help fulfil the goal of venture creation" (Katz \& Gartner, 1988; Choo \& Wong, 2006).

Entrepreneurship is a new and growing field in scientific research and education. A variety of 
academic efforts have focused on entrepreneurship education, thus helping this field to develop and gain momentum and contribute to the deeper understanding of the field. The concept of entrepreneurship education has also become an important economic and social phenomenon as well as a popular research subject which has become a promising area in academic and teaching field (Lekoko, Rankhumise \& Ras, 2012). Furthermore, the strategic importance of entrepreneurship in economic development has triggered the explosion of entrepreneurial education programs all throughout the world (Roxas et al., 2008).

Considering the importance of entrepreneurship for individuals and economies, a great emphasis has been attached to entrepreneurship education in a number of industrialized countries in the last two decades (Matlay \& Carey, 2007). As Matlay (2008, p. 382) acknowledged, "there is an expectation that more as well as better entrepreneurship education would result in a proportionate increase in both the number and the quality of entrepreneurs entering an economy". Creating and enhancing an entrepreneurial culture and environment has been provided as a solution for low productivity and decline in economic output for many years (Matlay, 2008). Therefore, as argued by Raposo, Paco, and Ferreira (2008) integration of the entrepreneurship into an academic curriculum can contribute to creating a suitable environment for learning and creativity, thus, increases awareness and knowledge in certain business fields. Entrepreneurship education also promotes a favourable psychological attitude towards entrepreneurs. Furthermore, there is an empirical evidence that entrepreneurship education programs impact on the entrepreneurial intentions (see Fayolle, Gailly \& Lassas-Clerc, 2006; Oosterbeek et al., 2010). Entrepreneurial intentions increase the tendency for business creation (Rodrigues, Raposo, Ferreira \& Paco, 2010) and result in entrepreneurial success (Dickson, Solomon \&Weaver, 2008). Although it has not yet been proven empirically, entrepreneurial attitudes that may encourage entrepreneurship as a career option can be highly effective even before high school (Kourilsky \& Walstad, 1998). Results of previous studies in the literature show that if certain types of education are promoted in the field of entrepreneurship, it results in a higher tendency for starting a business. Practice-oriented programs that provide an opportunity to have real experience can be effective in increasing the desire to start a new business (Honig, 2004). As mentioned in various studies, entrepreneurship education is required to include behavioural simulations and areas such as negotiation, leadership, creative thought, technological innovation and development of new products, discovery and exploration of new business opportunities, long-term business planning need to be focused (McMullan, Long \& Graham, 1986; Stumpf, Dunbar \& Mullen, 1991; Vesper \& McMullan, 1988). The role of entrepreneurial education and training in identifying potential entrepreneurial attitude especially at a young age is inevitable for students, educators and decision-makers (Rasheed, 2000). Therefore it is suggested that entrepreneurship education be integrated in the academic curricula at all levels from elementary school to university (Stevenson \& Lundstrom, 2001). As emphasized by Florin, Karri, and Rossiter (2007), it is not enough to teach necessary skills for entrepreneurship but, rather, it is essential to develop and enhance an "entrepreneurial drive". "Entrepreneurial drive" means how individual perceive the desirability and feasibility to pursue opportunities in a proactive manner and respond to challenging tasks, needs and obstacles in an innovative and creative way. According to a study by Raposo et al. (2008), it 
is necessary to foster the creation of start-ups in most countries and make the entrepreneurial career more appealing for younger generation. In the case of Portugal which was investigated in the study, the authors stated that, higher education institutions devoted a great deal of effort to improve "the entrepreneurial culture" at the beginning of the 21 st century. Entrepreneurship education can be used as a key for developing highly qualified human resources who are essential for creation of new businesses. Findings show that there is an increasing need to establish educational programs in the area of entrepreneurship education since academic education has an important impact on the acquisition of competences, attitudes and aspirations thus they can be helpful in improving and boosting the development of potential entrepreneurs (Raposo et al., 2008). As stated by Lynskey (2005), considering the role of higher education in societies and regional and national economic development, universities should be considered as "engines of knowledge". Therefore, it is necessary to develop and implement a proper national program which promotes entrepreneurship education among university students. In this way, it is possible to increase the number of start-ups especially in the field of technology.

It goes without saying that universities play a key role in bringing out the potential and talents of students, graduates and researchers. They are considered as societal innovation systems and there is a need to incorporate entrepreneurship education in this system. Therefore, while undertaking the task of training entrepreneurially oriented competent individuals, universities need to generate the social mechanisms that support and facilitate the birth and growth of businesses (Petridou, Sarri \&Kyrgidou, 2009, p. 290). Furthermore, universities are entrepreneurial hubs which bring together researchers, students, entrepreneurs, business enterprises and other stakeholders. Therefore entrepreneurship education is critical for developing entrepreneurial skills, attitudes and behaviours which are fundamental for economic growth. The positive influence of entrepreneurship education at universities in attitudes towards entrepreneurship promotes entrepreneurship as a useful and inspiring career path for graduates (Galloway \& Brown, 2002, p. 399). Considering this positive effect of entrepreneurship education, many universities offer entrepreneurship education at an advanced level with a great emphasis on writing business plans, acquiring start-up capital and developing managerial skills, particularly "nascent entrepreneurs" (see Matlay, 2006, p. 709; Lekoko et al., 2012).

However, as Gurol and Atsan (2006) stated, in Turkey, entrepreneurship education is far from being integrated into the national policy. Nevertheless, courses on entrepreneurship are offered as elective courses in undergraduate business administration programs of a limited number of Turkish universities. In a report prepared by TUSIAD [Turkish Industry \& Business Association] in 2002, masters and doctoral theses from all Turkish universities were reviewed, it was found that only 40 of them were related to the topic of entrepreneurship (TUSIAD Report, 2002). According to the report there is still a quest for what should constitute entrepreneurship education and how it should be designed at university level. When course content and syllabi were examined, it was found that students are generally trained in developing skills required for starting their businesses as well as small and medium sized enterprise management skills. However, Kirby (2004) states that a set of personal skills, 
attributes and behavior that go beyond the purely commercial reasons need to be developed by successful entrepreneurs. Entrepreneurs must be equipped with necessary set of skills and attributes, behaviors, and necessary way of thinking so that they become competent to meet and overcome the challenges of the twenty-first century encountered in the entrepreneurial climate. Therefore, it is vital to identify the personality traits and skills that are reflected by successful entrepreneurs in this way entrepreneurship education and training curriculum can be effectively designed in accordance with the needs of the country (Gurol \& Atsan, 2006).

Within this framework, the aim of this study is to shed some light on the effects of the impact on entrepreneurial intention of entrepreneurship education. In this context entrepreneurial intentions of the participants who haven't before taking any entrepreneurship education and have after taking an entrepreneurship education is determined. Based on present theories in the related literature and the results of previous studies, the following hypothesis was developed in the present study:

H1: Compared to control group, there is a significant difference between the entrepreneurial intentions of experimental group in the beginning of the term and those at the end of the term.

\section{Methodology of the Study}

\subsection{Aim of the Study and Sampling Process}

In this study which depends on the acknowledgement that "entrepreneur" is the dynamo of economic development in the realization of innovations mentioned by Schumpeter in his Theory of Economic Development, the aim is to determine the effects of entrepreneurship education on entrepreneurial intentions of innovation prone young population, namely undergraduate students who will receive such education during their undergraduate study. Within this perspective, it is aimed to find out whether there is a significant difference between the entrepreneurial intentions of business students who receive entrepreneurship education (experimental group) and business students who do not receive entrepreneurship education (control group) in the beginning and at the end of the term. Within this framework, it is envisaged that this study will greatly contribute to both national and international literature by analysing the effect of receiving entrepreneurship education on entrepreneurial intentions of undergraduate students who are believed to contribute to entrepreneurship ecosystem of Turkey, in this way limited scopes of previous studies will be extended.

Judgmental sampling in which the most suitable units are involved in sampling in accordance with the aim of the study was adopted in the present study. Considering time and cost limitations, the population of the study was determined as a total of $1901^{4}$ undergraduate students at Department of Business, Faculty of Economics and Administrative Sciences, Gazi University in the study year of 2014-2015. According to Sekaran, it is sufficient to have a sample size of 320 if the population is 1900 or to have a sample size of 322 if the population is 2000 (Sekaran, 2002, p. 294). Accordingly, the lower bound of sample size of the study was calculated as 322 using the formula $n=\pi(1-\pi) /(e / Z)^{2}$ with $95 \%$ confidence level and 5\% margin of error (Kurtulus, 2010, p. 67).

\footnotetext{
${ }^{4}$ The figure was obtained from IT Division of Gazi University during the term in which the study was carried out.
} 
Firstly, the survey was administered to 50 participants during pre-test then necessary adjustments and simplifications were made to the survey for enhancement of the data quality, then the final survey form was administered to the relevant sample of the study which was composed of registered students at the Department of Business in the study year of 2014-2015. Finally, based on voluntarily participation a total of 338 valid data were collected from 207 undergraduate students who received entrepreneurship education (experimental group) and 131 undergraduate students who did not receive entrepreneurship education (control group).

\subsection{Design of Experimental and Control Groups}

Experimental design of the study is presented in Table 1:

Table 1. Research Process

\begin{tabular}{|c|c|c|c|}
\hline Group & Beginning of Term & Procedure & End of Term \\
\hline EXPERIMENTAL GROUP & Measuring & Providing & Measuring \\
(207 Undergraduate Business Students) & Entrepreneurial & Entrepreneurship & Entrepreneurial \\
& Intention & Education & Intention \\
\hline CONTROL GROUP & Measuring & & Measuring \\
(131 Undergraduate Business Students) & Entrepreneurial & - & Entrepreneurial \\
& Intention & & Intention \\
\hline
\end{tabular}

While business students who received entrepreneurship education as experimental stimuli were chosen as experimental group, other business students who did not receive entrepreneurship education but resemble the experimental group in other aspects (those who have received another course from the same instructor who is giving the entrepreneurship course and who enrolled in the university in the same academic year) were determined as control group. The scale of entrepreneurial intention was administered to both experimental and control group in October 2014 in the beginning of fall term of 2014-2015 academic year in order to determine their entrepreneurial intentions. Then, a total of 207 students in the experimental group took "Entrepreneurship" course three hours a week for fifteen weeks, within this course these students were informed on theoretical and practical aspects of entrepreneurship such as development of entrepreneurship, fundamental concepts of entrepreneurship, functions of entrepreneurship, creation of value added, creativity and innovation in entrepreneurship, intrapreneurship, starting a business and forms of business realization, preparing business plan as the road map of entrepreneur (market analysis, technical analysis, financial analysis, management analysis, legal analysis). On the other hand, a total of 131 business students who did not take the course were not informed about such issues. The same scale was administered again to both experimental and control groups in January 2015 at the end of the term, and whether there was a significant difference between entrepreneurial intentions of students who received entrepreneurship education and those who did not receive entrepreneurship education in the beginning and at the end of the term was analysed and assessed.

Although data were collected from a total of 338 students who voluntarily participated in the 
study, a total of 10 bonus points were granted to participants in order to increase their motivation and engagement throughout data collection process; 5 bonus points were added to midterm exam scores of participants for filling out the survey in the beginning of the term and 5 bonus points were added to final exam scores of the participants for filling the survey at the end of the term.

\subsection{Developing Survey Form and Scales}

Face-to-face survey method was applied in the data collection process of the study. The survey was composed of two parts; the first part included items about tested variable which is entrepreneurial intention and the second part included items regarding the demographic features of participants and their conditions of whether they have received entrepreneurship education before. Items regarding entrepreneurial intention were taken from a present survey in the literature of which reliability and validity were tested in previous studies.

The scale which was used to measure participants' entrepreneurial intentions was developed by Boru (2006, p. 50) and was composed of five factors (innovation and action, determination and perseverance, challenges of starting business, negative thoughts on running one's own business, family support) and a total of 21 items. Items were asked in a 5-point Likert scale [(1) Strongly disagree...(5) Strongly agree]. The dimensions of "challenges of starting business" and "negative thoughts on running one's own business" which have negative associations were reverse coded.

\subsection{Analysis Method of Data}

IBM SPSS 21 statistics package program was used in the analysis of data. Internal consistency reliability of the variable of entrepreneurial intention was calculated. Then, T-test comparison was utilized in order to detect whether there was a significant difference between entrepreneurial intentions of students in the experimental group who received entrepreneurship education and students in the control group who did not receive entrepreneurship education in the beginning and at the end of the term.

\section{Methodology of the Study}

\subsection{Descriptive Statistics of the Sample}

Descriptive statistics regarding students in experimental and control groups can be found in Table 2: 
Table 2. Demographic Features of the Sample

\begin{tabular}{lcc}
\hline Gender & Frequency & Percent \\
\hline Female & 168 & 49.7 \\
Male & 170 & 50.3 \\
TOTAL & $\mathbf{3 3 8}$ & $\mathbf{1 0 0 . 0}$ \\
\hline Age & Frequency & Percent \\
\hline 20 & 97 & 28.7 \\
21 & 142 & 42.0 \\
22 & 99 & 29.3 \\
TOTAL & $\mathbf{3 3 8}$ & $\mathbf{1 0 0 . 0}$ \\
\hline
\end{tabular}

As can be seen in the table, in terms of their gender students who participated in the study were almost equally distributed between the groups. In terms of age, while age spectrum was between 20 and 22 for students who enrolled in the university in the same year, vast majority of participants was 21 years old. This finding of participants' age is consistent with the fact that the general profile of students who enrolled in the university in the same year and now are in their third years at the time of the study was supposed to be at the age of 21 .

In addition to demographic characteristics of participants, students were asked whether they have received any entrepreneurship education before so that experimental and control groups could be designed accordingly (Table 3 ).

Table 3. Sample's Condition of Receiving Entrepreneurship Education

\begin{tabular}{lcc}
\hline Condition of Receiving Entrepreneurship Education & Frequency & Percent \\
\hline With education (Experimental Group) & 207 & 61.2 \\
Without education (Control Group) & 131 & 38.8 \\
TOTAL & $\mathbf{3 3 8}$ & $\mathbf{1 0 0 . 0}$ \\
\hline
\end{tabular}

When we looked at the distribution regarding sample's condition of receiving entrepreneurship education before, it was found that $61.2 \%$ of sample which consisted of experimental group received entrepreneurship education for a whole term, $38.8 \%$ of sample which consisted of control group did not receive any entrepreneurship education.

\subsection{Validity Analysis}

In order to determine internal consistency value of variable of entrepreneurial intention, Cronbach's Alpha $(\alpha)$ reliability coefficient was calculated for experimental group as .724 in the beginning of term and as .788 at the end of term; it was calculated for control group as .751 in the beginning of term and as .703 at the end of term. It can be said that the scale used in the study was reliable considering the abovementioned reliability coefficients (Hair, Black, Babin, Anderson \& Tatham, 2006, p. 779).

\subsection{T-Test}

After the reliability of the scale of entrepreneurial intention was measured, the hypothesis which was formulated in the study was tested by using T-test. Within this regards, H1 
hypothesis was supported.

Whether there was a significant difference between entrepreneurial intentions of the experimental group before (first week of the relevant term) and after (fifteenth week of the relevant term) receiving entrepreneurship education was investigated through data gathered from 207 business students. Results of T-test applied to the data of relevant sample can be found in Table 4.

Table 4. T-test Results of the Comparison of Experimental Group's Conditions in the beginning and at the end of the term in terms of Entrepreneurial Intention and Dimension

\begin{tabular}{|c|c|c|c|c|c|c|c|}
\hline Variable & $\begin{array}{c}\text { Time of Survey } \\
\text { during Term }\end{array}$ & $\mathbf{N}$ & Mean & SD & df & $\mathbf{t}$ & $\mathbf{p}$ \\
\hline \multirow{2}{*}{$\begin{array}{l}\text { Entrepreneurial Intention } \\
(G E N E R A L)\end{array}$} & Beginning & 207 & 3.43 & .466 & \multirow{2}{*}{206} & \multirow{2}{*}{-13.464} & \multirow{2}{*}{$.000^{*}$} \\
\hline & End & 207 & 3.79 & .461 & & & \\
\hline \multirow{2}{*}{ Innovation and Action } & Beginning & 207 & 3.54 & .663 & \multirow{2}{*}{206} & \multirow{2}{*}{-1.852} & \multirow{2}{*}{.066} \\
\hline & End & 207 & 3.61 & .680 & & & \\
\hline \multirow{2}{*}{ Determination and Perseverance } & Beginning & 207 & 3.94 & .689 & \multirow{2}{*}{206} & \multirow{2}{*}{-14.271} & \multirow{2}{*}{$.000^{*}$} \\
\hline & End & 207 & 4.49 & .410 & & & \\
\hline \multirow{2}{*}{ Challenges of Starting Business } & Beginning & 207 & 2.92 & .793 & \multirow{2}{*}{206} & \multirow{2}{*}{-6.340} & \multirow{2}{*}{$.000^{*}$} \\
\hline & End & 207 & 3.29 & .788 & & & \\
\hline \multirow{2}{*}{$\begin{array}{l}\text { Negative Thoughts on Running } \\
\text { one's Own Business }\end{array}$} & Beginning & 207 & 3.01 & .830 & \multirow{2}{*}{206} & \multirow{2}{*}{-11.868} & \multirow{2}{*}{$.000^{*}$} \\
\hline & End & 207 & 3.78 & .839 & & & \\
\hline \multirow{2}{*}{ Family Support } & Beginning & 207 & 3.72 & 1.154 & \multirow{2}{*}{206} & \multirow{2}{*}{1.456} & \multirow{2}{*}{.147} \\
\hline & End & 207 & 3.62 & 1.145 & & & \\
\hline
\end{tabular}

$* \mathrm{p}<.01$

A significant difference was found between general entrepreneurial intentions of experimental groups before (beginning of term) and after (end of term) receiving entrepreneurship education $\left(\mathrm{t}_{(206)}=-13.464\right.$ and $\left.\mathrm{p}<.01\right)$. Therefore, it is seen that 15 -week entrepreneurship education which experimental group received had a positive effect on participants' entrepreneurial intentions. In other words, it can be said that entrepreneurship education increased entrepreneurial intentions of experimental group.

When a detailed assessment was carried out based on the results in terms of dimensions of entrepreneurial intention, it was found that except for the dimensions of "innovation and action" $\left(\mathrm{t}_{(206)}=-1.852\right.$ and $\left.\mathrm{p}>.05\right)$ and "family support" $\left(\mathrm{t}_{(206)}=1.456\right.$ and $\left.\mathrm{p}>.05\right)$, the entrepreneurial intention of experimental groups (received entrepreneurship education) was significantly different between in the beginning and at the end of the term in which the survey was administered in terms of the remaining three dimensions of entrepreneurial intention (Determination and Perseverance $\rightarrow \mathrm{t}_{(206)}=-14.271$ and $\mathrm{p}<.01$; Challenges of Starting Business $\rightarrow \mathrm{t}_{(206)}=-6.340$ and $\mathrm{p}<.01$; Negative Thoughts on Running one's Own Business $\rightarrow$ $t_{(206)}=-11.868$ and $\left.p<.01\right)$. Furthermore, it is seen that experimental group's averages at the end of the term were higher than their averages in the beginning of the term with regards to aforementioned three dimensions. According to these results, it can be stated that dimensions 
of "determination and perseverance", "challenges of starting business" and "negative thoughts on running one's own business" except for the dimensions of "innovation and action" and "family support" sufficiently supported the main hypothesis (H1). In other words, while experimental group's entrepreneurial intentions in the beginning and at the end of the term did not cause any differences in terms of the dimensions of "innovation and action" and "family support", it caused a significant difference in terms of the dimensions of "determination and perseverance", "challenges of starting business" and "negative thoughts on running one's own business" (Table 4).

Whether there was a significant difference between entrepreneurial intentions of the control group in the beginning and at the end of the term was investigated through data gathered from 131 business students. Results of T-test applied to the data of relevant sample can be found in Table 5.

Table 5. T-test Results of the Comparison of Control Group's Conditions in the beginning and at the end of the term in terms of Entrepreneurial Intention and Dimension

\begin{tabular}{|c|c|c|c|c|c|c|c|}
\hline Variable & $\begin{array}{c}\text { Time of Survey } \\
\text { during Term }\end{array}$ & $\mathbf{N}$ & Mean & SD & df & $\mathbf{t}$ & $\mathbf{p}$ \\
\hline \multirow{2}{*}{$\begin{array}{l}\text { Entrepreneurial Intention } \\
(G E N E R A L)\end{array}$} & Beginning & 131 & 3.45 & .487 & \multirow{2}{*}{130} & \multirow{2}{*}{-.633} & \multirow{2}{*}{.528} \\
\hline & End & 131 & 3.47 & .440 & & & \\
\hline \multirow{2}{*}{ Innovation and Action } & Beginning & 131 & 3.60 & .734 & \multirow{2}{*}{130} & \multirow{2}{*}{.919} & \multirow{2}{*}{.360} \\
\hline & End & 131 & 3.56 & .721 & & & \\
\hline \multirow{2}{*}{ Determination and Perseverance } & Beginning & 131 & 3.84 & .690 & \multirow{2}{*}{130} & \multirow{2}{*}{-1.768} & \multirow{2}{*}{.079} \\
\hline & End & 131 & 3.93 & .641 & & & \\
\hline \multirow{2}{*}{ Challenges of Starting Business } & Beginning & 131 & 3.07 & .861 & \multirow{2}{*}{130} & \multirow{2}{*}{.414} & \multirow{2}{*}{.680} \\
\hline & End & 131 & 3.04 & .761 & & & \\
\hline \multirow{2}{*}{$\begin{array}{l}\text { Negative Thoughts on Running } \\
\text { one's Own Business }\end{array}$} & Beginning & 131 & 3.42 & .813 & \multirow{2}{*}{130} & \multirow{2}{*}{-.949} & \multirow{2}{*}{.344} \\
\hline & End & 131 & 3.49 & .839 & & & \\
\hline \multirow{2}{*}{ Family Support } & Beginning & 131 & 2.76 & 1.073 & \multirow{2}{*}{130} & \multirow{2}{*}{-.154} & \multirow{2}{*}{.878} \\
\hline & End & 131 & 2.79 & 1.043 & & & \\
\hline & & & & & & & \\
\hline
\end{tabular}

Control group of the study did not receive any kind of entrepreneurship education (experimental stimulus was not administered), whether there was a significant difference between general entrepreneurial intentions of the control group in the beginning and at the end of the term was investigated and no significant difference was found at the significance level of $.05\left(t_{(130)}=-.633\right.$ and $\mathrm{p}>$.05). As anticipated, there was not any significant difference between entrepreneurial intentions of control group in the beginning and at the end of the term.

Any significant difference was not observed in terms of each and every dimension of entrepreneurial intention. (Innovation and Action $\rightarrow t_{(130)}=.919$ and $p>.05$; Determination and Perseverance $\rightarrow t_{(130)}=$ -1.768 and $p>.05$; Challenges of Starting Business $\rightarrow t_{(130)}=.414$ and $p>.05$; Negative Thoughts on Running One's Own Business $\rightarrow \mathrm{t}_{(130)}=-.949$ and $\mathrm{p}>.05$; Family Support $\rightarrow \mathrm{t}_{(130)}=-.154$ and $\mathrm{p}>.05$ ). In other words, entrepreneurial intentions of control groups in the beginning and at the end of the term 
did not differ significantly as expected in all dimensions of entrepreneurial intention (Table 5).

\section{Conclusion and Suggestions}

A vast majority of studies on entrepreneurship in the literature measure participants' already existing entrepreneurial intentions (Naktiyok \& Timuroglu, 2009; Chen, Hsiao, Chang, Chou, Chen \& Shen, 2015; Paco, Ferreira, Raposo, Rodrigues \& Dinis, 2015; Uysal \& Guney, 2016; Entrialgo \& Iglesias, 2016) or entrepreneurial tendencies (Goksel \& Aydintan, 2011; Bilge \& Bal, 2012; Fafaliou, 2012; Khuong \& An, 2016), and aim to associate these features with especially age, gender, general education (Iscan \& Kaygin, 2011) and whether there is already an entrepreneur in the family or relatives cycle (Linan, Rodriguez-Cohard \& Rueda-Cantuche, 2011; Celik, Ince \& Bozyigit, 2014). Moreover, a majority of studies involving students as subjects also aim to investigate students' already existing entrepreneurial intentions within the framework of demographic characteristics. In some studies, whether studying in different departments has any effect on entrepreneurial intentions of students is measured (Marangoz, Kaya \& Bakan, 2014).

The present study, on the other hand, focuses on the students of department business who are believed to contribute intellectually to the economy as entrepreneurs and managers and who are trained accordingly in their departments, and the aim of the study is to investigate whether 15-week of entrepreneurship education would increase already existing entrepreneurial intentions of such students. Therefore, what distinguishes this study from others in the literature is that the measurement of the effect of entrepreneurship education was carried out by using a control group involving business students who did not receive any education on the topic. In other words, this study tries to find out whether there is any significant difference between entrepreneurship levels of similar two groups; one receiving education and another not receiving any education. This positivist deterministic scientific approach requires having a control groups in research, which makes the approach distinctive among other research approaches.

Within this framework, it was found that there was a statistically significant increase in entrepreneurial intentions of students who received entrepreneurship education. This finding proves that education or training can increase entrepreneurial intention and certainly shows the positive effect of departments of business in Turkey on students' entrepreneurial intentions. The present study reveals that increased entrepreneurial intentions of those who received entrepreneurship education are especially statistically significant in terms of the dimensions of determination and perseverance, starting business and running their own business. These findings show that entrepreneurship education enhances individuals' determination and perseverance, increases thoughts of encountering fewer challenges while starting a business, and decreases negative thoughts on running their own businesses. Furthermore, entrepreneurship education positively affects and increases the innovation and action dimension of entrepreneurial intention. The study scientifically confirms that entrepreneurial intention can be increased through education and entrepreneurship education can play a positive role in bringing new entrepreneurs to the economy.

It is obvious that such studies can contribute to preparing national economic and education 
policies. It is envisaged that information which is an indispensable part of economy, together with educated people who obtain and produce information, and who adapt and interpret the information will greatly contribute to national development and welfare through entrepreneurship education.

In the future, it will be useful to carry out studies which include control groups and larger samples in their research design, and which especially take into account different demographic characteristics so that findings of present studies in the literature can be better tested and developed. For example, results of studies which investigate the effect of entrepreneurship education with comparisons to a control group in samples receiving vocational/technical education focusing on developing competences such as mechanical hand skills can greatly contribute to the literature. It is envisaged that the present study will yield scientific benefits and contributions to managerial implementation if it is expanded in a way including employees and actual entrepreneurs in the environment. In addition to these, different designs of entrepreneurship education including features such as theoretical and practical issues, education structure, communication method and internship and their effects on individuals' entrepreneurial intentions should be further investigated. Considering the fact that entrepreneurship is the fundamental power of economy, it can be put forward that the increase in the importance attached to entrepreneurship education will become one of fundamental dynamics of national development.

\section{References}

Acs, Z. J., \& Storey, D. J. (2004). Introduction: Entrepreneurship and economic development. Regional Studies, 38(8), 871-877. https://doi.org/10.1080/0034340042000280901

Balaban, O., \& Ozdemir, Y. (2008). Girisimcilik egitiminin girisimcilik egilimi uzerindeki etkisi: Sakarya Universitesi IIBF ornegi [The effect of entrepreneurship education on entrepreneurial tendency: A case of Sakarya University Faculty of Economics and Administrative Sciences]. Girisimcilik ve Kalkinma Dergisi [Journal of Entrepreneurship and Development], 3(2), 133-147.

Baron, R. A. (1998). Cognitive mechanism in entrepreneurship: Why and when entrepreneurs think differently than other people. Journal of Business Venturing, 13(4), 275-294. https://doi.org/10.1016/S0883-9026(97)00031-1

Bilge, H., \& Bal, V. (2012). Girisimcilik egilimi: Celal Bayar Universitesi ögrencileri uzerine bir arastirma [Entrepreneurship aptitude: An empirical study on undergraduate and vocational high school students in Celal Bayar University]. Suleyman Demirel Universitesi Sosyal Bilimler Enstitusu Dergisi [Journal of Suleyman Demirel University Institute of Social Sciences], 16(2), 131-148.

Bird, B. (1988). Implementing entrepreneurial ideas: The case for intention. Academy of Management Review, 13(3), 442-453. https://doi.org/10.2307/258091

Bozkurt, O., Aslan, Z., \& Goral, M. (2011). Yuksekogretimde verilen girisimcilik egitiminin ogrencilerin girisimcilik egilimine etkisi: Teknik program ve sosyal program karsilastirmali 
bir arastirma [The effect of entrepreneurship education provided at higher education level on entrepreneurial tendency: A comparative study of technical programme and social programme]. Uluslararası Yuksekogretim Kongresi: Yeni Yonelisler ve Sorunlar [International Congress of Higher Education: New Trends and Problems], Istanbul, 822-833.

Boru, D. (2006). Girisimcilik egilimi: Marmara Universitesi isletme bolumu ögrencileri uzerine bir arastirma [Entrepreneurial tendency: A study on students of department of business administration at Marmara University]. Marmara Universitesi Yayini [Publication of Marmara University], No: 733, Istanbul.

Bygrave, W. D., \& Hofer, C. W. (1991). Theorizing about entrepreneurship. Entrepreneurship Theory and Practice, 16(2), 13-22.

Charney, A., \& Libecap, G. D. (2000). The impact of entrepreneurship education: An evaluation of the Berger entrepreneurship program at the University of Arizona, 1985-1999. Kansas: The Kauffman Center for Entrepreneurial Leadership Research Series. The Ewing Marion Kauffman Foundation.

Chen, S., Hsiao, H., Chang, J., Chou, C., Chen, C., \& Shen, C. (2015). Can the entrepreneurship course improve the entrepreneurial intentions of students?. International Entrepreneurship and Management Journal, 11(3), 557-569. https://doi.org/10.1007/s11365-013-0293-0

Choo, S., \& Wong, M. (2006). Entrepreneurial intention: Triggers and barriers to new venture creations in Singapore. Singapore Management Review, 28(2), 47-64.

Coulter, M. A. (2003). Entrepreneurship in action (2nd ed.). New Jersey: Pearson Education Inc.

Celik, A., Ince, M., \& Bozyigit, S. (2014). Universite ogrencilerinin girisimcilik niyetlerini etkileyen ailesel faktorleri belirlemeye yonelik bir calisma [A study to determine family elements affecting entrepreneurship intention of college students]. Omer Halisdemir Universitesi Iktisadi ve Idari Bilimler Fakultesi Dergisi [Omer Halisdemir University Academic Review of Economics and Administrative Sciences], 7(3), 113-124.

Clercq, D. D., \& Arenius, P. (2006). The role of knowledge in business start-up activity. International Small Business Journal, 24(4), 339-358. https://doi.org/10.1177/0266242606065507

Dickson, P. H., Solomon, G. T., \& Weaver, K. M. (2008). Entrepreneurial selection and success: Does education matter?. Journal of Small Business and Enterprise Development, 15(2), 239-258. https://doi.org/10.1108/14626000810871655

Donnellon, A., Ollila, S., \& Middleton, K. W. (2014). Constructing entrepreneurial identity in entrepreneurship education. The International Journal of Management Education, 12(3), 490-499. https://doi.org/10.1016/j.ijme.2014.05.004

Elert, N., Andersson, F. W., \& Wennberg, K. (2015). The impact of entrepreneurship education in high school on long-term entrepreneurial performance. Journal of Economic 
Behavior \& Organization, 111, 209-223. https://doi.org/10.1016/j.jebo.2014.12.020

Entrialgo, M., \& Iglesias, V. (2016). The moderating role of entrepreneurship education on the antecedents of entrepreneurial intention. International Entrepreneurship and Management Journal, 12(4); 1209-1232. https://doi.org/10.1007/s11365-016-0389-4

Fafaliou, I. (2012). Students' propensity to entrepreneurship: an exploratory study from Greece. International Journal of Innovation and Regional Development, 4(3/4), 293-313. https://doi.org/10.1504/IJIRD.2012.047563

Fayolle, A., \& Gailly, B. (2004). Using the theory of planned behaviour to assess entrepreneurship teaching programs: A first experimentation. 14. Annual IntEnt Conference, University of Napoli Federico II (Italy), July 4-7.

Fayolle, A., Gailly, B., \& Lassas-Clerc, N. (2006). Assessing the impact of entrepreneurship education programmes: A new methodology. Journal of European Industrial Training, 30(9), 701-720. https://doi.org/10.1108/03090590610715022

Florin, J., Karri, R., \& Rossiter, N. (2007). Fostering entrepreneurial drive in business education: An attitudinal approach. Journal of Management Education, 31(1), 17-42. https://doi.org/10.1177/1052562905282023

Galloway, L., \& Brown, W. (2002). Entrepreneurship education at university: A driver in the creation of high growth firms. Education + Training, 44(8/9), 398-405. https://doi.org/10.1108/00400910210449231

Goksel, A., \& Aydintan, B. (2011). Gender, business education, family background and personal traits; A multi dimensional analysis of their affects on entrepreneurial propensity: Findings from Turkey. International Journal of Business and Social Science, 2(13), 35-48.

Gurol, Y., \& Atsan N. (2006). Entrepreneurial characteristics amongst university students: Some insights for entrepreneurship education and training in Turkey. Education + Training, 48(1), 25-38. https://doi.org/10.1108/00400910610645716

Hair, J. F., Black, W. C., Babin, B. J., Anderson, R. E., \& Tatham, R. L. (2006). Multivariate data analysis (6th ed.). New Jersey: Pearson Prentice Hall.

Hisrich, R. D., Peters, M. P., \& Shepherd, D. A. (2005). Entrepreneurship. Boston, MA: McGraw-Hill Irwin.

Honig, B. (2004). Entrepreneurship education: Toward a model of contingency-based business planning. Academy of Management Learning and Education, 3(3), 258-273. https://doi.org/10.5465/AMLE.2004.14242112

Huber, L. R., Sloof, R., \& Praag, M. V. (2012). The effect of early entrepreneurship education: Evidence from a randomized field experiment. The Institute for the Study of Labor (IZA) Discussion Paper Series.

Izedonmi, P. F., \& Okafor, C. (2010). The effect of entrepreneurship education on students' entrepreneurial intentions. Global Journal of Management and Business Research, 10(6), 
49-60.

Iscan, Ö. F., \& Kaygin, E. (2011). Universite ogrencilerinin girisimcilik egilimlerini belirlemeye yonelik bir arastirma [An Investigation to Determine the Entrepreneurship Tendency of University Students]. Ataturk Universitesi Sosyal Bilimler Enstitusu Dergisi [Ataturk University Journal of Social Sciences Institute], 15(2): 443-462.

Karlsson, T., \& Moberg, K. (2013). Improving perceived entrepreneurial abilities through education: Exploratory testing of an entrepreneurial self-efficacy scale in a pre-post setting. The International Journal of Management Education, 11(1), 1-11. https://doi.org/10.1016/j.ijme.2012.10.001

Katz, J., \& Gartner, W. B. (1988). Properties of emerging organizations. Academy of Management Review, 13(3), 429-441. https://doi.org/10.2307/258090

Khuong, M. N., \& An, N. H. (2016). The factors affecting entrepreneurial intention of the students of Vietnam National University-A mediation analysis of perception toward entrepreneurship. Journal of Economics, Business and Management, 4(2), 104-111. https://doi.org/10.7763/JOEBM.2016.V4.375

Kirby, D. A. (2004). Entrepreneurship education: Can business schools meet the challenge?. Education + Training, 46(8/9), 510-519. https://doi.org/10.1108/00400910410569632

Kourilsky, M. L., \& Esfandiari, M. (1997). Entrepreneurship education and lower socioeconomic black youth: An empirical investigation. The Urban Review, 29(3), 205-215. https://doi.org/10.1023/A:1024629027806

Kourilsky, M. L., \& Walstad, W. B. (1998). Entrepreneurship and female youth: Knowledge, attitudes, gender differences, and educational practices. Journal of Business Venturing, 13(1), 77-88. https://doi.org/10.1016/S0883-9026(97)00032-3

Kurtulus, K. (2010). Arastirma yontemleri [Research methods]. İstanbul: Turkmen Kitabevi.

Krueger, N. F. Jr., \& Brazeal, D. V. (1994). Entrepreneurial potential and potential entrepreneurs. Entrepreneurship Theory and Practice, 18(3), 91-104.

Lekoko, M., Rankhumise, E. M., \& Ras, P. (2012). The effectiveness of entrepreneurship education: What matters most?. African Journal of Business Management, 6(51), 12023-12032. https://doi.org/10.5897/AJBMx12.001

Linan, F., Rodriguez-Cohard, J. C., \& Rueda-Cantuche, J. M. (2011). Factors affecting entrepreneurial intention levels: A role for education. International Entrepreneurship and Management Journal, 7(2), 195-218. https://doi.org/10.1007/s11365-010-0154-Z

Lynskey, M. J. (2005). Editorial: Moving beyond metaphors: University-industry collaboration in biotechnology. Journal of Commercial Biotechnology, 11(4), 301-304. https://doi.org/10.1057/palgrave.jcb.3040130

Marangoz, M., Kaya, F., \& Bakan, H. (2014). Egitim alani girisimcilik niyetini nasil etkilemektedir? Universite ogrencilerine yonelik bir inceleme [How does field of education 
affect entrepreneurial intentions? A Research of university students]. Mugla Sitki Kocman Universitesi Ekonomi ve Yonetim Arastirmalari Dergisi [Mugla Sitki Kocman University Journal of Economics and Management Research], 3(1), 75-96.

Matlay, H. (2006). Researching entrepreneurship and education: Part 2: What is entrepreneurship education and does it matter?. Education + Training, 48(8/9), 704-718. https://doi.org/10.1108/00400910610710119

Matlay, H., \& Carey, C. (2007). Entrepreneurship education in the UK: A longitudinal perspective. Journal of Small Business and Enterprise Development, 14(2), 252-263. https://doi.org/10.1108/14626000710746682

Matlay, H. (2008). The impact of entrepreneurship education on entrepreneurial outcomes. Journal of Small Business and Enterprise Development, 15(2), 382-396. https://doi.org/10.1108/14626000810871745

McLarty, R. (2005). Entrepreneurship among graduates: Towards a measured response. Journal of Management Development, 24(3), 223-238. https://doi.org/10.1108/02621710510584044

McMullan, W. E., Long, W. A., \& Graham, J. B. (1986). Assessing economic value added by university-based new-venture outreach programs. Journal of Business Venturing, 1(2), 225-240. https://doi.org/10.1016/0883-9026(86)90016-9

Naktiyok, A., \& Timuroglu, M. K. (2009). Ogrencilerin motivasyonel degerlerinin girisimcilik niyetleri uzerine etkisi ve bir uygulama [The effect of students' motivational values on their entrepreneurial intentions and an application]. Ataturk Universitesi Iktisadi ve Idari Bilimler Dergisi [Ataturk University Journal of Economics and Administrative Sciences], 23(3), 85-103.

Obschonka, M., Silbereisen, R. K., \& Schmitt-Rodermund, E. (2010). Entrepreneurial intention as developmental outcome. Journal of Vocational Behavior, 77(1), 63-72. https://doi.org/10.1016/j.jvb.2010.02.008

Olson, P. D. (1986). Entrepreneurs: Opportunistic decision makers. Journal of Small Business Management, 24, 29-35.

Oosterbeek, H., Praag, M. V., \& Ijsselstein, A. (2010). The impact of entrepreneurship education on entrepreneurship skills and motivation. European Economic Review, 54(3), 442-454. https://doi.org/10.1016/j.euroecorev.2009.08.002

Paco, A. D., Ferreira, J. M., Raposo, M., Rodrigues, R. G., \& Dinis, A. (2015). Entrepreneurial intentions: Is education enough?. International Entrepreneurship and Management Journal, 11(1), 57-75. https://doi.org/10.1007/s11365-013-0280-5

Petridou, E., Sarri, A., \& Kyrgidou, L. P. (2009). Entrepreneurship education in higher educational institutions: The gender dimension. Gender in Management: An International Journal, 24(4), 286-309. https://doi.org/10.1108/17542410910961569 
Rasheed, H. S. (2000). Developing entrepreneurial potential in youth: The effects of entrepreneurial education and venture creation. United States Association for Small Business and Entrepreneurship Annual National Conference. Florida: University of South Florida.

Rodrigues, R., Raposo, M., Ferreira, J., \& Paco, A. (2010). Entrepreneurship education and the propensity for business creation: Testing a structural model. International Journal of $\begin{array}{llll}\text { Entrepreneurship } \quad \text { and } & \text { Small }\end{array}$ https://doi.org/10.1504/IJESB.2010.029506

Raposo, M., Paco, A., \& Ferreira, J. (2008). Entrepreneur's profile: A taxonomy of attributes and motivations of university students. Journal of Small Business and Enterprise Development, 15(2), 405-418. https://doi.org/10.1108/14626000810871763

Roxas, B. G., Cayoca-Panizales, R., \& Jesus, R. M. (2008). Entrepreneurial knowledge and its effects on entrepreneurial intentions: Development of a conceptual framework. Asia-Pacific Social Science Review, 8(2), 61-77.

Sekaran, U. (2002). Research methods for business: A skill building approach (4th ed.). USA: John Wiley \& Sons Inc.

Shane, S., \& Venkataraman, S. (2000). The promise of entrepreneurship as a field of research. Academy of Management Review, 25(1), 217-226. https://doi.org/10.2307/259271

Stevenson, L., \& Lundstrom, A. (2001). Patterns and trends in entrepreneurship/SME policy and practice in ten economies (Volume 3), Entrepreneurship policy for the future series. Stockholm: Swedish Foundation for Small Business Research.

Stumpf, S. S., Dunbar, R. L. M., \& Mullen, T. P. (1991). Simulations in entrepreneurship education: Oxymoron or untapped opportunity?. Frontiers of Entrepreneurship Research, Babson College: Wellesley, MA: 681-694.

Tagraf, H., \& Halis, M. (2008). Universitelerdeki girisimcilik egitiminin girisimsel oz yetkinlik algisi uzerindeki etkisi: Bir arastirma [Effect of entrepreneurship educations at universities on entrepreneurship self-perfection perception: A research]. Canakkale Onsekiz Mart Universitesi Girisimcilik ve Kalkinma Dergisi [Canakkale Onsekiz Mart University Journal of Entrepreneurship and Development], 3(2), 91-111.

Tang, L., \& Koveos, P. E. (2004). Venture entrepreneurship, innovation entrepreneurship, and economic growth. Journal of Developmental Entrepreneurship, 9(2), 161-171.

Turkish Industry \& Business Association (TUSIAD) Report (2002). Turkiye'de girisimcilik [Entrepreneurship in Turkey]. Retrieved file://C:/Users/User/Downloads/girisimcilik.pdf

Ulukoy, M., Demireli, C., \& Kahya, V. (2013). Kosgeb girisimcilik egitimi kurslarina katilan katilimcilarin girisimcilik profiline yonelik bir alan arastirmasi [A field survey entrepreneurial profile of participants who are participating in Kosgeb entrepreneurship education course]. Canakkale Onsekiz Mart Universitesi Girisimcilik ve Kalkinma Dergisi [Canakkale Onsekiz Mart University Journal of Entrepreneurship and Development], 8(2), 79-96. 


\section{Macrothink}

Journal of Management Research

ISSN 1941-899X 2017, Vol. 9, No. 3

Uysal, B., \& Guney, S. (2016). Entrepreneurial intentions of Turkish business students: An exploration using Shapero's model. Journal of Administrative Sciences, 14(28), 27-47.

Vesper, K. H., \& McMullan, W. E. (1988). Entrepreneurship: Today courses, tomorrow degrees?. Entrepreneurship Theory and Practice, 13(1), 7-13.

\section{Copyright Disclaimer}

Copyright for this article is retained by the author(s), with first publication rights granted to the journal.

This is an open-access article distributed under the terms and conditions of the Creative Commons Attribution license (http://creativecommons.org/licenses/by/3.0/). 